\title{
Игорь Николаевич Денисов
}

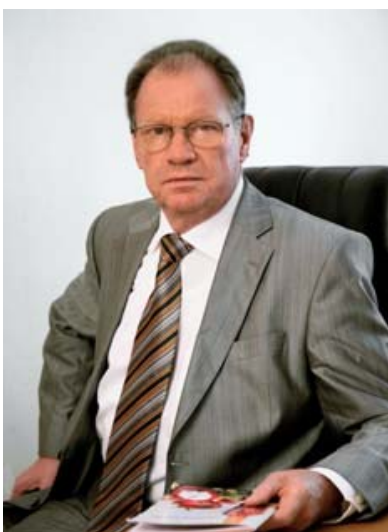

2 сентября 2016 г. исполнилось 75 лет доктору медицинских наук, профессору, академику РАН Игорю Николаевичу Денисову - советскому и российскому государственному деятелю, организатору здравоохранения, медицинской науки и медицинского образования, советнику ректора Первого МГМУ им. И.М. Сеченова, заведующему кафедрой семейной медицины Института профессионального образования.

И.Н. Денисов родился в г. Свободном Хабаровского края. Мать - врач, отец - служащий. В 1964 г. окончил Куйбышевский медицинский институт, овладев специальностью хирурга. В этом же институте успешно прошел путь от клинического ординатора до доктора медицинских наук, проректора по учебной работе (1964-1983 гг.), в течение 5 лет был секретарем парткома (1973-1978 гг.). Его диссертации (кандидатская - в 1970, докторская - в 1982) посвящены исследованиям в области прямой трансфузии крови, лечению раневой инфекции, биостимуляции органов при хирургических операциях. Эффективно совмещая научно-педагогическую, организационную и общественную работу, Игорь Николаевич сформировал в себе высокопрофессиональные навыки руководителя.

С 1983 по 1987 г. Игорь Николаевич был ректором Рязанского медицинского института. В условиях коренных изменений, происходящих в социальной и экономической сферах жизни нашего общества, он работал на руководящих постах в Министерстве здравоохранения CССР: начальником Главного управления учебных заведений (1987), заместителем Министра (1987-1988), первым заместителем Министра (1988-1990), Министром здравоохранения СССР (1990-1991). Был членом ЦК КПСС (1990-1991). С 1988 г. возглавлял общество «СССР - Перу», являлся президентом Российской ассоциации друзей Латинской Америки.

После завершения министерской карьеры Игорь Николаевич работает в ГБОУ ВПО «Первый Московский государственный медицинский университет им. И.М. Сеченова»: проректором (1991-2004), первым проректором (2004-2011), советником ректора (с 2011 г.). В 1994 г. был избран членом-корреспондентом PAMН, в 2000 г. - академиком РАМН, в 2013 г. - академиком РАН.

На протяжении многих лет Игорь Николаевич возглавлял Экспертный совет по медико-профилактическим наукам в Высшей аттестационной комиссии (BAK) и Диссертационный совет университета по специальностям «Общественное здоровье и здравоохранение, «Социология медицины», «Гигиена».

Академик И.Н. Денисов, долгие годы являясь заместителем председателя совета Учебно-методического объединения по высшему медицинскому и фармацевтическому образованию, заместителем председателя Ассоциации медицинских и фармацевтических вузов России, уделял огромное внимание развитию медицинского образования в России. Под его руководством были разработаны программы, а также образовательные стандарты для высшего и последипломного учебного звена.

И.Н. Денисов - один из ведущих отечественных специалистов в области управления здравоохранением и подготовки медицинских кадров; инициатор перевода учреждений здравоохранения на новые условия хозяйствования, создания экономической заинтересованности медицинских работников в конечных результатах своего труда. При его активном участии сформирована служба экстренной медицины, заложены основы страховой медицины, издан первый отечественный сборник по страховой медицине; велась разработка концепции непрерывной подготовки врачебных кадров, государственных образовательных стандартов для медицинских и фармацевтических вузов и медицинских факультетов государственных университетов, нормативных и информационных материалов по аттестации специалистов здравоохранения. Он является автором и руководителем исследований по развитию высшего медицинского и фармацевтического образования, повышению квалификации врачебных и провизорских кадров, становлению и развитию системы медицинского страхования, первичной медико-санитарной помощи, общей врачебной практики (семейной медицины) и медицинской профилактики. И.Н. Денисов плодотворно сочетает работу в Первом МГМУ им. И.М. Сеченова с должностными назначениями в различных государственных, профессиональных и общественных органах, структурах и организациях: он главный внештатный специалист общей врачебной практики (семейный врач) Министерства здравоохранения Российской Федерации, председатель профильной комиссии Экспертного совета в сфере здравоохранения Министерства здравоохранения Российской Федерации по специальности «Общая врачебная практика (семейная медицина)», член Координационного совета по развитию непрерывного медицинского и фармацевтического образования Минздрава России, член Центральной аттестационной комиссии Министерства здравоохранения Российской Федерации и Ассоциации медицинских обществ по качеству (АСМОК).

В 1992 г. И.Н. Денисов организовал первую в России кафедру семейной медицины. Сторонники этого направления не ожидали, что внедрение семейной медицины окажется настолько трудным делом и найдет такой неоднозначный отклик в медицинской среде, но им повезло в том, что у истоков начинания стоял Игорь Николаевич. Сейчас в России около 50 кафедр и курсов семейной медицины. В государственных и муниципальных учреждениях трудятся более 10000 врачей общей практики.

В 2000 г. была создана и в 2001 г. зарегистрирована Общероссийская общественная организация «Ассоциация врачей общей практики (семейных врачей) Российской Федерации» (РАВОП), президентом которой стал Игорь Николаевич (с 2001 г.). К настоящему времени 
проведено 4 съезда РАВОП - в Самаре (2001), Чебоксарах (2004), Белгороде (2008), Казани (2013). А сколько за это время проведено конференций, совещаний и выездных циклов переподготовки врачей!

Игорь Николаевич стоял у истоков освоения новых образовательных технологий в обучении медицинских работников. На кафедре семейной медицины были разработаны и внедрены дистанционное образование для врачей с использованием телекоммуникационных технологий и интернета, система накопительных кредитов в непрерывном медицинском образовании, кредитномодульная организация учебного процесса.

По заданию Министерства здравоохранения Российской Федерации сотрудники кафедры семейной медицины под руководством И.Н. Денисова занимаются разработкой нормативных документов по общей врачебной практике - приказов, порядков оказания медицинской помощи, клинических рекомендаций для врачей общей практики, профессиональных стандартов. Кафедра участвовала в таких проектах Министерства образования Российской Федерации, как «Образование», «Развитие системы оценки качества профессионального образования на основе создания и внедрения механизмов сертификации квалификаций специалистов и выпускников образовательных учреждений с учетом интеграции требований Федерального государственного образовательного стандарта и профессиональных стандартов».

Кафедра семейной медицины под руководством академика И.Н. Денисова участвовала в стартовавшей 1 января 2006 г. программе по повышению качества медицинской помощи, объявленной Президентом Российской Федерации В.В. Путиным, - национальном проекте «Здоровье». В рамках развития первичной медико-санитарной помощи проводила мероприятия по подготовке и переподготовке врачей общей практики.

Игоря Николаевича как профессионала в области организации здравоохранения, медицинского образования и семейной медицины знают не только в России, но и в ближнем и дальнем зарубежье, его приглашают на международные конгрессы, конференции, симпозиумы.

Под руководством академика И.Н. Денисова кафедра семейной медицины участвовала в многочисленных международных проектах по таким направлениям, как «доказательная медицина» и «общая врачебная практика (семейная медицина)», наиболее крупные из них - программа Евросоюза «Тасис», проект «Развитие первичной медицинской помощи по принципу семейного врача», пилотный проект «Реформа здравоохранения» как компонент «Национальной программы подготовки кадров в области семейной медицины» Всемирного банка. Выполнялось несколько проектов Европейского отделения Всемирной организации здравоохранения по борьбе с туберкулезом и фонда «Российское здравоохранение» по подготовке преподавателей для обучения медицинских работников общей лечебной сети системы здравоохранения в рамках программы «Развитие стратегии лечения населения Российской Федерации, уязвимого к туберкулезу». С 2008 г. РАВОП является членом Всемирной ассоциации врачей общей практики (WONCA), а академик И.Н. Денисов - членом Американской академии семейных врачей.

Общая врачебная практика - только один аспект многогранной научной и практической деятельности Игоря Николаевича. Несмотря на занятость, он много лет является членом Консультационного совета РЖД, главным редактором журналов «Врач» и «Вестник семейной медицины», председателем редакционного совета журнала «Справочник врача общей практики», членом редакционного совета журнала Белорусского государственного медицинского университета (Белоруссия); членом редакционных коллегий журналов «История медицины», «Проблемы социальной гигиены», «Медицинская сестра».

Игорь Николаевич - автор более 600 печатных работ, в числе которых монографии, клинические руководства, клинические рекомендации, изобретения, защищенные патентами и авторскими свидетельствами. Им подготовлены 15 докторов и более 20 кандидатов медицинских наук.

Многолетний и плодотворный труд И.Н. Денисова отмечен многочисленными почетными званиями, наградами и премиями: орденом Трудового Красного Знамени (1991), медалью «В память 850-летия Москвы» (1997), орденом Дружбы (2002), медалью «За взаимодействие с ФСБ» (2007), нагрудным знаком «Отличник здравоохранения». За выдающиеся достижения в науке и организации здравоохранения Игорь Николаевич был удостоен премии Правительства РФ в области образования за 2000 и 2004 гг. и премии Правительства РФ в области науки и техники за 2007 г.

Игорь Николаевич - человек высочайшей культуры, большой эрудиции и энциклопедического склада ума. При решении любых вопросов его отличают стратегическое мышление, широкий кругозор, высокий профессионализм, доступность и простота в общении. Он всегда делится своим огромным жизненным опытом с молодежью и коллегами, радуется успехам своих учеников, которые работают как в различных регионах России, так и за рубежом. Отличительными чертами Игоря Николаевича Денисова являются его исключительная целеустремленность, личная скромность, принципиальность, честность, отзывчивость, доброжелательность и удивительное трудолюбие.

Свое 75-летие Игорь Николаевич встречает с большими творческими планами в период возросшего интереса органов государственной власти к общей врачебной практике (семейной медицине), развитию которой он посвящает свой опыт, знания и талант руководителя.

Бюро Отделения медицинских наук РАН, редколлегия журнала «Вестник РАМН», многочисленные ученики, друзья и коллеги сердечно поздравляют глубокоуважаемого Игоря Николаевича с юбилеем и желают ему крепкого здоровья, счастья, благополучия, долгих лет жизни и дальнейших творческих успехов на благо отечественной медицинской науки, здравоохранения и образования! 